NBER WORKING PAPER SERIES

THE IMPACT OF RAINFALL ON RICE OUTPUT IN INDONESIA

David I. Levine

Dean Yang

Working Paper 20302

http://www.nber.org/papers/w20302

\author{
NATIONAL BUREAU OF ECONOMIC RESEARCH \\ 1050 Massachusetts Avenue \\ Cambridge, MA 02138 \\ July 2014
}

This paper was previously circulated under the title "The Impact of Rainfall on Rice Output in Indonesian Districts." Thanks are due to Jules Elkins for excellent research assistance. The views expressed herein are those of the authors and do not necessarily reflect the views of the National Bureau of Economic Research.

NBER working papers are circulated for discussion and comment purposes. They have not been peerreviewed or been subject to the review by the NBER Board of Directors that accompanies official NBER publications.

(C) 2014 by David I. Levine and Dean Yang. All rights reserved. Short sections of text, not to exceed two paragraphs, may be quoted without explicit permission provided that full credit, including $₫$ notice, is given to the source. 
The Impact of Rainfall on Rice Output in Indonesia

David I. Levine and Dean Yang

NBER Working Paper No. 20302

July 2014

JEL No. O13

\begin{abstract}
We estimate the impact of weather variation on agricultural output in Indonesia by examining the impact of local rainfall shocks on rice output at the district level. Our analysis makes use of local meteorological data on rainfall in combination with government administrative data on district-level rice output in the 1990s. We find that deviations from mean local rainfall are positively associated with district-level rice output. $10 \%$ higher rainfall leads metric tons of rice output to be $0.4 \%$ higher on average. The impact of rainfall on rice output occurs contemporaneously (in the same calendar year), rather than with a lag. These results suggest that researchers should be justified in interpreting higher rainfall as a positive contemporaneous shock to local economic conditions in Indonesia.
\end{abstract}

David I. Levine

Haas School of Business

University of California

Berkeley CA 94720-1900

levine@haas.berkeley.edu

Dean Yang

University of Michigan

Department of Economics and

Gerald R. Ford School of Public Policy

735 S. State Street, Room 3316

Ann Arbor, MI 48109

and NBER

deanyang@umich.edu 


\title{
The Impact of Rainfall on Rice Output in Indonesia
}

\author{
David I. Levine \\ Haas School of Business \\ University of California, Berkeley \\ Dean Yang* \\ Department of Economics and Gerald R. Ford School of Public Policy \\ University of Michigan
}

July 9,2014

\section{Introduction and summary}

Life in rural areas of developing countries is prone to many kinds of risk, such as illness or mortality of household members, crop or other income loss due to natural phenomena (weather, insect infestations, or fire, for example), and civil conflict. Empirical work in development economics often examines the impact of exogenous shocks of various sorts on households, as a way of shedding light on various economic phenomena such as the quality and nature of household risk sharing and consumption smoothing mechanisms, intrahousehold allocation decisions, gender bias, and the long-run consequences of shocks experienced in vulnerable periods of life (such as infancy, or school-age years). Many papers examine the impact of weather variation, and in particular rainfall. Examples include Rose (1999), Hoddinott and Kinsey (2001), Jensen (2000), Miguel, Satyanath, and Sergenti (2004), Miguel (2005), Newhouse (2005), and Maccini and Yang (2009). ${ }^{1}$

${ }^{*}$ Corresponding author. Email: deanyang@umich.edu. Address: 3315 Weill Hall, 735 S. State St., Ann Arbor, MI 48109. This paper was previously circulated under the title "The Impact of Rainfall on Rice Output in Indonesian Districts." Thanks are due to Jules Elkins for excellent research assistance.

${ }^{1}$ Additional examples include Akresh et al (2011), Ampaabeng and Tan (2013), Bjorkman-Nyquist (2013), Bruckner et al (2014), Datar et al (2013), Dell et al (2012), Porter (2012), Rabassa et al (2014), Skoufias and Vinha (2012), Sotomayor (2013), and Thai and Falaris (2014). Currie and Vogl (2013) provide a review of the literature on the long-run impact of early-life conditions. 
A particularly fruitful body of research along these lines has focused on Indonesia, for many reasons including the availability of a number of high quality datasets from the Indonesian government as well as outside organizations (RAND's Indonesia Family Life Survey being the most prominent). Examples of recent work which have examined the impact of shocks on Indonesian households are Frankenberg, Smith, and Thomas (2003), Newhouse (2005), Maccini and Yang (2009), and Yamauchi (2012).

The purpose of this short paper is confirm that rainfall is a positive shock to agricultural output in Indonesia by examining the impact of district-level rainfall shocks on local rice output in the 1990s. These results justify the interpretation of rainfall as a positive shock to local areas in Indonesia. This is particularly important for research that examines the reduced-form impact of rainfall shocks on various outcomes without being able to simultaneously examine rainfall's contemporaneous impact on crop output.

The remainder of this paper consists of the following sections. Section 2 describes the data used, section 3 carries out the empirical analysis, and section 4 provides an overall summary and implications for researchers. The final section contains references. A single regression results table follows.

\section{Data}

\section{$2.1 \quad$ Rainfall data}

Our focus is on local rainfall variation. Rainfall is the most important dimension of weather variation in Indonesia; the country's location astride the equator means that temperature shows very little variation, either within years or across them (Library of Congress, 2003). Indonesian rainfall exhibits substantial variability within year across districts as well as within districts over time. In any particular year, the length of the wet season and the intensity of drought during the dry season vary markedly across Indonesia, and sometimes within small geographic units. ${ }^{2}$ The specific trajectories of the monsoons vary from one year to the next, which combined with differences in local topography leads to wide variation in precipitation across the archipelago both within year and across years (Library of Congress 2003). This variety within Indonesia is perhaps not surprising, given that the country's 13,700 islands span 5,100 kilometers from east to west

\footnotetext{
${ }^{2}$ In the wet season, $200 \mathrm{~mm}$ or more of rain falls per month. This definition is based on the minimum threshold necessary for rice production and takes into account evaporation and seepage through the soil (Kishore et al., 2000).
} 
and cross three time zones.

Indonesia's climate consists simply of one wet season and one dry season each year. The distinguishing feature of the wet season is that at least $200 \mathrm{~mm}$ or more of rain falls per month, and in the dry season mean rainfall is less than that threshold. ${ }^{3}$ The specific months of the wet and dry season vary across Indonesian provinces, and we take these differences into account when constructing our rainfall variable.

We obtain historical rainfall data for weather stations across Indonesia from the Global Historical Climatology Network (GHCN) Precipitation and Temperature Data (Version 2). The data include monthly records for each rainfall station as well as the latitude and longitude of the station's location. We use the station location information to match each district represented in the IFLS to the closest rainfall station. ${ }^{4}$ We disallow matches between districts and rainfall stations that are more than 500 kilometers apart.

In calculating rainfall in a particular year, we focus on rainfall in complete wet and dry seasons (rather than in calendar years), as these should be most closely related to agricultural cycles. We start by defining the months included in the wet and dry seasons in each Indonesian province. ${ }^{5}$ Depending on the province, the wet season starts anywhere from September to December, while the dry season can start as early as March and as late as June. For example, in the province of Central Java the wet season runs from October to April, and the dry season from May to September. Then we identify the month of the start of the wet season of the previous calendar year (either Sep., Oct., Nov., or Dec., depending on province) and measure rainfall at the district (kabupaten) level for the 12 months that follow.

In analyses of the impact of annual rainfall on rice output, we focus on the deviation of annual rainfall from the norm for one's birth district. Specifically, the variable is the natural log of annual rainfall minus the natural log of mean annual rainfall in the given district. Mean district rainfall is calculated over 1953-1999, but excludes rainfall in the given year (i.e., mean annual rainfall used in calculating the rainfall deviation variable for 1995 excludes the year 1995 in calculation of the mean).

\footnotetext{
${ }^{3}$ This definition is based on the minimum threshold necessary for rice production and takes into account evaporation and seepage through the soil (Kishore et al., 2000).

${ }^{4}$ These data are produced jointly by the National Climatic Data Center, Arizona State University, and Carbon Dioxide Information Analysis Center at Oak Ridge National Laboratory and are available at http://www.ncdc.noaa.gov/oa/climate/research/ghcn/ghcn.html. Because the number of rainfall stations varies over time, data from different rainfall stations may be linked to the same district over time.

${ }^{5}$ To do this, we combine information from secondary reports on the extent of the rainy season (Kishore et al., 2000) with our own analysis of mean monthly rainfall across all weather stations within each province.
} 


\subsection{Rice output data}

Data on rice output in metric tons at the kabupaten level were purchased in paper format from the Indonesia Bureau of Statistics (BPS) for the years 1993-1999. These data were manually entered into an electronic database, and then the data were cleaned to impute data for missing districts on the basis of output in other districts within the same province. Rice output is measured over the calendar year (Jan.-Dec.).

\section{Empirical estimates}

The empirical analysis involves estimating via OLS regressions of the following form for rice output in district $i$ and year $t$ :

$$
\ln Y_{i t}=\alpha_{0}+\alpha_{1} R_{i t}+\mu_{i}+\delta_{t}+\varepsilon_{i t}
$$

The dependent variable $\ln Y_{i j}$ is the natural $\log$ of rice output in metric tons, for Indonesian districts (kabupatens) from 1993 to 1999. The independent variable of interest, $R_{i t}$, is the deviation of log rainfall from log mean district rainfall over 1953-1999. The regressions also include fixed effects for district $\left(\mu_{i}\right)$ and year $\left(\delta_{t}\right)$. $\varepsilon_{i t}$ is a mean-zero error term.

Regression results are presented in the accompanying table. Across various specifications, we examine the effect of current rainfall on rice output in subsets of districts according to major city (kotamadya) status (columns 1-3), as well as the effect of rainfall in the past and future across these same district subsets (columns 4-6).

Column 1 presents results from a regression that includes all districts, and indicates that higher rainfall leads to higher rice output. The coefficient on the rainfall variable is positive and significant at the $10 \%$ level. Because the effect of rainfall is likely to differ across rural and urban areas, the following columns present results from the same regression, but for districts excluding major cities (column 2), and for districts that are major cities (column 3). The result in column 2 indicates that rainfall has a positive effect on rice output outside of major cities that is statistically significant at the $5 \%$ level. On the other hand, there is no evidence of a relationship between rainfall and rice output in major cities: in column 3 , the coefficient on rainfall is not statistically significantly different from zero. ${ }^{6}$

\footnotetext{
${ }^{6}$ Somewhat surprisingly, the coefficient on rainfall in column 3 is much larger than the coefficients in the previous columns. However, this coefficient is very imprecisely estimated so not much further can be said on this front.
} 
To better understand the timing of rainfall that matters for rice output, columns 4-6 of the table present regression results analogous to those in columns 1-3, but where one lag and one lead of the rainfall variable are included in the regressions. Across the three sample definitions, the coefficients on the current rainfall variable are little changed vis-a-vis columns 1-3. Moreover, the coefficients on lag and lead rainfall are all close to zero and none of them enter statistically significantly in the regressions. The results in columns 4-6 suggest that current-year rainfall matters most for current-year rice output.

\section{Summary and implications}

In summary, we find that higher local rainfall leads to higher rice output in Indonesian districts. $10 \%$ higher rainfall leads metric tons of rice output to be $0.4 \%$ higher on average. In addition, the impact of rainfall on rice output occurs contemporaneously (in the same calendar year), rather than with a lag. These results suggest that researchers should be justified in interpreting higher rainfall as a positive shock to the fortunes of local areas in Indonesia, at least in terms of its impact on rice output. These are likely to lead to higher household incomes in localities, both directly and via general equilibrium effects. Rainfall shocks may appropriately be interpreted as contemporaneous (as opposed to lagged) shocks to locality-level rice output.

Furthermore, we only find statistically significant effects of rainfall in districts that are not major cities. Researchers examining the impact of local rainfall shocks in Indonesia on various outcomes should therefore exclude major cities (kotamadja) from their analyses.

\section{References}

Akresh, Richard, Philip Verwimp, Tom Bundervoet (2011). "Civil War, Crop Failure, and Child Stunting in Rwanda," Economic Development and Cultural Change, 59:4, 777-810.

Ampaabeng, Samuel K., Chih Ming Tan (2013). "The long-term cognitive consequences of early childhood malnutrition: The case of famine in Ghana," Journal of Health Economics, 32:6, December, 1013-1027.

Björkman-Nyqvist, Martina (2013). "Income shocks and gender gaps in education: Evidence from Uganda," Journal of Development Economics, 105, 237-253.

Bruckner, Tim A., Gerard J. van den Berg, Kirk R. Smith, Ralph A. Catalano (2014). "Ambient temperature during gestation and cold-related adult mortality in a Swedish cohort, 1915- 
2002," Social Science ES Medicine.

Currie, Janet and Tom Vogl (2013). "Early-Life Health and Adult Circumstance in Developing Countries," Annual Review of Economics, 5:1, 1-36.

Datar, Ashlesha, Jenny Liu, Sebastian Linnemayr, Chad Stecher (2013). "The impact of natural disasters on child health and investments in rural India," Social Science $E$ S Medicine, 76, 83-91.

Dell, Melissa, Benjamin F. Jones, Benjamin A. Olken (2012). "Temperature Shocks and Economic Growth: Evidence from the Last Half Century," American Economic Journal: Macroeconomics, 4:3, 66-95.

Frankenberg, Elizabeth, James P. Smith, and Duncan Thomas (2003). "Economic Shocks, Wealth, and Welfare," Journal of Human Resources, 38(2), 280-321.

Hoddinott, John and Bill Kinsey (2001). "Child Growth in the Time of Drought," Oxford Bulletin of Economics and Statistics, 63 (4), 409-436.

Jensen, Robert (2000). "Agricultural Volatility and Investments in Children," AEA Papers and Proceedings, 90 (2), 399-404.

Kishore, Kamal, A R Subbiah, Tien Sribimawati, Sri Diharto, Sutarto Alimoeso, Peter Rogers, Adang Setiana (2000). "Indonesia Country Study," Asian Disaster Preparedness Center. Available at: www.unu.edu/env/govern/ElNino/CountryReports/pdf/Indonesia.pdf.

Library of Congress (2003). Indonesia. Country Studies/Area Handbook Series: Federal Research Division.

Maccini, Sharon and Dean Yang (2009). "Under the Weather: Health, Schooling, and Economic Consequences of Early-Life Rainfall," American Economic Review, 99(3), June, 1006-1026.

Miguel, Edward, Shanker Satyanath and Ernest Sergenti (2004). "Economic Shocks and Civil Conflict: An Instrumental Variables Approach," Journal of Political Economy, 112 (4), 725-753.

Miguel, Edward (2005). "Poverty and Witch Killing," Review of Economic Studies, 72, 11531172.

Newhouse, David (2005). "The Persistence of Income Shocks: Evidence from Rural Indonesia," Review of Development Economics, 9(3): 415-433.

Catherine Porter (2012). "Shocks, Consumption and Income Diversification in Rural Ethiopia," Journal of Development Studies, 48:9, 1209-1222.

Rabassa, M., E. Skoufias, H. Jacoby (2014). "Weather and Child Health in Rural Nigeria," Journal of African Economies.

Rose, Eliana (1999). "Consumption Smoothing and Excess Female Mortality in Rural India," 
Review of Economics and Statistics, 81 (1), February, 41-49.

Skoufias, Emmanuel, Katja Vinha (2012). "Climate variability and child height in rural Mexico," Economics 65 Human Biology, 10(1), 54-73.

Sotomayor, Orlando (2013). "Fetal and infant origins of diabetes and ill health: Evidence from Puerto Rico's 1928 and 1932 hurricanes," Economics \& Human Biology, 11:3, 281-293.

Thai, Thuan Q., Evangelos M. Falaris (2014). "Child Schooling, Child Health, and Rainfall Shocks: Evidence from Rural Vietnam," Journal of Development Studies, 50, 1025-1037.

Yamauchi, Futoshi (2012). "Prenatal Seasonality, Child Growth, and Schooling Investments: Evidence from Rural Indonesia," Journal of Development Studies, 48:9, 1323-1341. 
Effect of current rainfall on rice production, Indonesian districts 1993-1999

(Fixed effects estimates)

Dependent variable: Ln (annual rice output, metric tons)

(2)

(3)

(4)

(5)

(6)

\section{Sample of districts:}

$\begin{array}{ccc}\text { All } & \begin{array}{c}\text { Excluding } \\ \text { major cities }\end{array} & \begin{array}{c}\text { Major cities } \\ \text { only }\end{array} \\ 0.045 & 0.042 & 0.121 \\ (0.023)^{\star} & (0.019)^{\star *} & (0.209)\end{array}$

All

Excluding major cities

Major cities

Deviation of log rainfall from norm (current year)

$(0.023)^{*}$

$(0.019)^{\star \star}$

(0.209)

0.045

$(0.024)^{*}$

0.041

$(0.020)^{*}$

0.088

Deviation of log rainfall from norm (year before)

0.008

0.012

(0.028)

(0.024)

$-0.028$

$-0.012$

$-0.012$

(0.029)

(0.025)

(0.290)

Deviation of log rainfall from norm (year after)

Y

Year fixed effects

District fixed effects

$\begin{array}{cc}Y & Y \\ Y & Y \\ 0.99 & 0.98 \\ 1495 & 1385\end{array}$

$Y$
$Y$
0.99
110

$Y$
$Y$

Y

R-squared

Num. of obs.

1385

110

0.99

1495

$Y$
$Y$
0.98
1385

$\mathrm{Y}$

Y

0.99

110

* significant at $10 \%$; ** significant at $5 \%$; ** significant at $1 \%$

NOTES-- Sample is Indonesian districts from 1993 to 1999. Some districts are missing data in certain years. Standard errors clustered by province. Dependent variable is In(annual rice output in metric tons). Rice output measured over the calendar year (Jan.-Dec.). Rainfall variable is deviation of log rainfall from log of 1953-1999 district mean rainfall. Rainfall measured at the district (kabupaten) level for 12 months beginning the start of the wet season of the previous calendar year (either Sep., Oct., Nov., or Dec., depending on province). "Major cities" (kotamadya) are defined by Indonesian Bureau of Statistics (BPS). 